Ramon, X., Billings, A.C., \& Rojas-Torrijos, J.L. (2019). Interviews With Former ESPN Ombudsmen/

Public Editors Kelly McBride, Robert Lipsyte, and Jim Brady. International Journal of Sport

Communication, 12(1), 28-35. https://journals.humankinetics.com/view/journals/ijsc/12/1/article-p28.xml

\title{
Interviews with Former ESPN Ombudsmen / Public Editors \\ Kelly McBride, Robert Lipsyte, and Jim Brady
}

\author{
Xavier Ramon \\ Universitat Pompeu Fabra, Spain \\ Andrew C. Billings \\ University of Alabama, USA \\ José Luis Rojas Torrijos \\ Universidad de Sevilla, Spain
}

ESPN, the self-proclaimed (yet rarely disputed) "Worldwide Leader in Sports", has long realized it was much more than an entertainment company. Acknowledging that with great power comes great responsibility, ESPN assigned George Solomon the title of first "Ombudsman" in 2005, functioning much like a referee ensuring that sports journalism exhibited the standard of being accountable to the ethical norms of the profession. For 13 years, six ESPN ombudsmen collectively served in this role. On May 2018, however, the company discontinued this position, arguing it had outlived its usefulness against the real-time feedback provided by social media. With the role of ombudsman discontinued, the last three ESPN Ombudsmen/Public Editors were interviewed to 
ascertain their impressions of the impact of their role and the changing status of ESPN. Kelly McBride is a writer, teacher and media ethics expert at the The Poynter Institute for Media Studies (St. Petersburg, Florida); as part of the Poynter Review Project, she served as ESPN ombudsman between 2011 and 2012. Robert Lipsyte is a sports journalist who started his career in 1957 as an editorial assistant for The New York Times; throughout his career, he has written for The New York Post and USA Today and has been a correspondent for CBS and NBC, serving as the ESPN ombudsman in 2013-2014. Jim Brady is a former sports and executive editor at WashingtonPost.com and editor-in-chief of Digital First Media. More recently, he serves as the CEO of Spirited Media; he served as the ESPN Ombudsman from November 2015 to March 2018. These interviews, conducted between August and September 2018, provide insight into the presumed value of this role, the prominent issues each ombudsman tackled, their relationship with ESPN staff, and the challenges that the organization faces in the current media landscape. Altogether, these conversations capture a greater idea of the value that this unique position delivered as well as reflect on what was lost after ESPN decided to eliminate it. Interviewed separately, the three responses are nevertheless combined here for better thematic flow and word economy.

\section{Authors: How would you define your role as ombudsman when you served there at ESPN?}

McBride: We were meant to be 'the explainers'. ESPN is such as massive organization. So much of what they do is mysterious and not transparent. There were always so many questions about what ESPN's true stance was for any variety of journalistic actions 
that they took. Our role was to sort through those questions, figure out which ones were really interesting and could lead to revelations about the organization, and then pursue the answers to those questions so we could do two things: hold ESPN accountable and educate the public about how ESPN operates.

Lipsyte: When ESPN called and asked if I'd like to be on a short list to be their fifth Ombudsman, my first question was 'What's an Ombudsman?' They more or less said, "Anything you make of it," so I said, "Sure." I went up and met the thirtyperson editorial group and I told them that I had no agenda, although keeping ESPN's journalism honest would be my first priority, even though conflict of interest would always be the elephant in the room. According to Patrick Stiegman, my handler for the scheduled 18-month gig, I was "appropriately provocative," which I guess meant I sounded like I might rock the boat but wouldn't tip it over. I declared that there would be no boundaries for the ombudsman. Philosophy and ethics dogma would be secondary to transparency, I said: explaining how something had actually happened, whether it was ESPN's slow response to Pittsburgh quarterback Ben Roethlisberger's alleged sexual transgressions or the company's love affair with Tim Tebow, would be my priority. I said that I didn't plan to be a presence on Twitter; the ombudsman should be reflective not reflexive. I would write once a month, more often if there was a breaking story. I mentioned a few recent incidents I thought had been handled poorly by management, especially the punishments of two employees who had used the phrase "a chink in his armor" when referring to the Chinese-American basketball player Jeremy Lin. 
Such ongoing ESPN problems as poor supervision and the reliance on clichés seemed more to blame than racism. How about using such incidents as teachable moments?

Brady: We changed the role a little bit when I took it. We all agreed that we needed to change a little. We didn't want to spend every week writing three columns about 'ESPN suspended this personality because they said this and this is a good decision or a bad decision'. I wanted it to be much more about larger trends inside ESPN, with a focus on journalism matters rather than 'the police procedurals'.

Lipsyte: In a riff that I was told made a particularly strong impression on the board, I said that I envisioned the job as window-washing. I would be the window-washer, creating transparency. For ESPN, I think, desperate to achieve journalistic legitimacy, an ombudsman offered an honest attempt at integrity. It wasn't all show, but there was no question there was trepidation. No one likes oversight. And there was no real journalistic DNA in ESPN's heritage. It was created to broadcast games. Journalistic coverage and commentary were later created in the same spirit as promotional devices to create audiences for the games - chatter before and after as a form of commercials for the event.

\section{Authors: How did you choose which stories to tackle? Which ones were more sensitive than others?}


McBride: Ultimately, it was my own personal judgement about what was interesting. That said, it was informed significantly by both audience interest and other media interest. If these key media writers were writing about a topic, it would be hard for the ombudsman to stay away from that topic. LeBron's decision to leave Cleveland and play for the Miami Heat is the classic one. Everybody wrote about that. Obviously, the ombudsman of ESPN also needed to address that. But I also wrote and explored a couple of topics for which I knew there wasn't a public drumbeat but I was really interested in them. A lot of times this had to do with some of the more offbeat things ESPN covers or more interesting broader ethical questions. An example of that is that I did a piece on whether or not ESPN should show the video of the little boys crying in the Little League World Series. I loved that topic, but ESPN thought I was crazy when I said that I wanted to write about that. Some of the hardcore ESPN fans weren't thrilled with that choice, but it allowed me to explore broader issues or assumptions that people were making about boys in sports. If ESPN was covering the Little League World Series, what did that mean?

Lipsyte: I would take my cues from the ombudsman's mailbag, using reporting to answer the audience's questions. I think I got about 1,000 e-mails a month. I had an assistant but I tried to read them all, which was easier than it sounds - so many called for the firing of an announcer they didn't like or for more coverage of, say, hockey or a particular region of the country which, I would explain in stock answers, just wasn't in my power. I answered thoughtful emails, particularly those critical of my opinions, which often led to rewarding exchanges. 
Brady: I'd write stories about things that I thought were larger trends, not one-off things. For instance, people's use of social media is clearly a trend and represents a potential problem every day at ESPN. That's not just about politics; it's about getting ahead of the story. Social media is a dangerous weapon for a lot of reasons as a well as, obviously, a great platform for other things. I didn't get too much into debate shows. I referenced them a few times, especially in the last pieces. They make a ridiculous amount of money. We can all sit here and complain about it, but at the end of the day, all businesses have cash cows and those cash cows fund things that are not cash cows. Because First Take is so successful Outside the Lines can get proper funding. I wanted it to be more like a blend of opinion and reporting and I called a lot of people for almost everything I wrote. I really wanted the voices of people who work there as well. But I certainly added my opinion but, more than that, I just didn't want to be uninformed. I tried to ask people 'what are you guys talking about on the inside?', 'what did you say in meetings?', 'what are the internal issues that you talk about?'.

\section{Authors: Do you remember a particular theme or column that you wrote during your time as ombudsman that seemed to overly resonate with the audience?}

Lipsyte: $\quad$ Ten days after I had been told the job was mine but more than a month before I would actually start, Jason Collins, a popular, hard-charging 6 foot 8 inch veteran of 12 NBA seasons, announced in a Sports Illustrated essay that he was gay. On 
ESPN's best journalism show, Outside the Lines, the network's lead pro basketball reporter, Chris Broussard, declared, 'If you're openly living in unrepentant sin, whatever it may be, not just homosexuality [but] adultery, fornication, premarital sex between heterosexuals ... I believe that's walking in open rebellion to God and to Jesus Christ.' How did a reporter come to say that? On a sports show? What would be ESPN's reaction, and why? What would the audience think? It would be old news by the time I posted, but I thought it was a big enough story with enough ramifications to justify being my first column. It touched on so many of the issues I wanted to address in my 'ombudtime': What are the boundaries of sports talk, and on which shows; what is the distinction between a reporter and a commentator; how can ESPN balance the varying sensibilities of its audience, not to mention balancing the demands of its "partners," the teams, conferences, leagues whose games it airs and analyzes? There was also a personal aspect; as a New York Times columnist I had written about three athletes, a high school linebacker, a former major league outfielder, and a former NFL lineman who came out. The first two were on the front page, the third on the back page of the sports section. Gay fatigue was setting in even though the topic of gays in sports was important to ways we think about manhood and team dynamics. I wanted to press on with this story even in a secondary way by covering the coverage. Writing about this wasn't going to change the attitudes of sports or even of ESPN, but maybe I could nudge the coverage toward something closer to fairness and reality. LZ Granderson and Broussard both knew who their constituencies were and played to them. I had more of a problem with the slipshod way ESPN had prepared for this story. At the least, 
it could have connected more dots to other gay sports stories, perhaps even link to the gay struggle for equal rights and its push-back and to the spike in assaults on gay men. Just what does this story mean, if anything, to sports, to gays, to the perception of manhood in America?

Brady: There was a year or so without one between Robert Lipsyte and I. In that period of time, Grantland got shut down. I don't think they were too excited that I was reopening this thing that had largely been discussed. They had moved on from it. I felt it was important to go back and make sure that things were not left uncovered because they happened during a 'dead' period. My piece was not popular with some of the Grantland folks that hold a belief that the only reason Grantland died is because ESPN had tampered with it. I talked to a lot of people inside and outside ESPN including people with Grantland background that felt people inside Grantland deserved some of the blame too. That definitely created some problems that it never overcame. I can't say I wish I wanted to have written it differently, but there is this subset of the 'Grantland club' that just won't take criticism.

McBride: There's a number of themes that fall into certain categories. One is: how do you apply the generally accepted journalistic standards to sports? A second one is: what's news and what's entertainment? For example, you cover college football because it's entertaining, not because it's news. But when a coach at Penn State is indicted for child sexual abuse, you have to switch from covering college football as entertainment and start treating it like a news issue. After Jerry Sandusky was 
indicted, we called ESPN out for missing the true story for the first 72 hours, where they spent most of the time talking about what was going to happen to Penn State's recruiting chances, not focusing as much on the culture of sexual abuse. A third theme is the conflict between the business model and the true journalism model, which happens when you talk about LeBron James' decision or covering the NFL concussion crisis. The fourth one is about access in journalism. That's where my Bruce Feldman story comes in [Feldman wrote a book for college football coach Mike Leach, who was suing ESPN for libel]. One of the things that makes ESPN very valuable is that it has resources that are deeply embedded in whatever sport it is; it could be anything from mixed-martial arts to the NFL. In order to get that further access and to gain that type deep knowledge, you need an extraordinary amount of time with your sources but those sources are not your audience, so there is a conflict between what your audience wants from you and what your source wants from you. That was a massively complicated issue for which I came down very hard on everyone involved, including ESPN and Bruce Feldman. Bruce Feldman's fans did not like that at all. It was the column in which I took most grief and the most criticism. I didn't remember much about the column until I re-read it, but from the criticism you would think that I totally exonerated ESPN. But no, I shared the blame, but part of that was on Feldman as a journalist for creating the conflict of interest.

\section{Authors: Are there any columns you wrote in your time as ombudsman that you regret or would rethink with the benefit of hindsight?}


Brady: I wrote pieces that were interesting to the fans that didn't do very well, like one about how ESPN decides to introduce new technology into broadcasting. Then, during the Jemele Hill controvers, on Twitter, when I was trying to respond to people, I had a couple of unfortunate tweets. At one point, I wrote that the media is the only reason people think Donald Trump is a White supremacist. People said I was blaming the media. If you read the 150 tweets I wrote before, I was saying that if you want to beat up on the press, remember that the reporting of the press is part of the reason people know about some of the Trump's more controversial actions in the first place. People took that out of context, people were retweeting this like, 'oh my god, he is basically blaming the press for Donald Trump being racist.' People are using things against you that they know don't reflect what you actually mean. We live in a world where there is not a battle of ideas, it is a battle of partisans. It's trying to take the other side out of the fight rather than debating things honestly. I learned that valuable lesson that night.

McBride: No regrets for what I wrote at the time I wrote it. I had an assistant do small amounts of blogging; I had an editor here at Poynter in addition to the editing at ESPN. Unlike all of the other ombudsman, I was doing it as a representative of The Poynter Institute, so I had a team giving me a deep amount of confidence as a I chose the topics and executed them. More brains helped me to figure out what the real issues were and whether I was really hitting it, if the way I framed the issue was going to be helpful for the audience. 
Lipsyte: I probably have issued with all of my columns, probably, if I could get myself to re-read them.

\section{Authors: Who were the people that you worked most closely with? How helpful was ESPN staff during your tenure? How much autonomy did you feel you had?}

Lipsyte: Most ESPN journalists I called were cooperative, even when it was apparent I was criticizing them - I made it clear that they would have a chance to state their cases. The overwhelming viewer concern was the intrusion of "social issues" into game coverage, whether that meant religion or homosexuality or race. They wanted a "safe place" for their family to watch without having to deal with the real world. I had some sympathy with that point of view even if it was unrealistic, sports and politics have always been linked. Occasionally, I would have some pushback from former athletes now ESPN broadcasters who couldn't understand why they weren't just being petted by a fellow employee - I'd have to explain the role of an ombudsman and that I'd be writing about them even if they gave me a hard time, which I would also then write about. End of problem. I would have more of a problem with a few top executives who assumed they were speaking off the record because of their positions. I did not honor off-the-record unless it was stated upfront. They learned. 
McBride: My point person was Patrick Stiegman and I felt a lot of freedom. Sometimes I would pick a topic and he would say 'OK, to cover this topic, here are the people you should be talking to'. Then they would put me in contact with the people, but the people didn't have any obligation to talk to me. ESPN didn't require that they talk to me. Sometimes I got some pushback from some people who didn't want to talk to me or didn't think that I knew what I was doing and didn't feel that I deserved their time. There was one time when someone high up at ESPN said 'I can't believe you are covering this when we have this other topic that you should be covering'. That was the one time that I felt any pressure at all. There were times when I picked a column and they didn't like it, but I didn’t feel pressured to not cover it.

Brady: Patrick Stiegman was also my lead contact. He was the person that I would talk to about what I was going to write next. I had access to a lot of the people and I think we were largely aligned. They definitely had their concerns about certain pieces. I think they wish I had been doing fewer pieces on ESPN's connections to politics on social media, because I think that was a moving target that they were struggling with but, in general, it was a good experience. They never said 'you can write about that or don't write about that'. The furthest I ever went is when [then ESPN President] John Skipper didn't want to talk to me about the Grantland thing, but they didn't say: 'don't write the story'. They said 'Skipper is not going to be available for this one'. But it was a good experience and I am glad I did it. 
Authors: In May 2018, ESPN announced it discontinued the Ombudsman/Public Editor position. The company stated that "the position had outlived its usefulness, largely because of the rise of real-time feedback of all kinds". Can a "horde of watchdogs" substitute the critical, independent and informed analysis provided by an ombudsman/public editor?

McBride: I don't agree with that stance mainly because that was true even when I was in the role. That certainly didn't make the role obsolete. In fact, it made it even more relevant because there is so much noise out there and it gives people an opportunity to interact with a neutral third party who cares deeply about sports and ESPN's influence over it.

Brady: The metaphor I use to describe to somebody the difference between public feedback and having a really embedded ombudsman is that the public is sort of like a dermatologist that can see what is on the outside; they can see what you publish and they can react to those kinds of things. However, the ombudsman is sort of like a cardiologist; he or she knows what is going on inside. Most people who are sitting on the outside aren't able to get to ESPN executives relatively easily to get them to talk through things. I don't know why the volume of the voices matters. I have always thought that is a weak argument.

McBride: I do think that the role was significant. I feel like I influenced people both inside ESPN and outside the organization. I felt I changed ESPN in different ways. They 
never said 'you are so right, so we are going to change this policy', but after the Bruce Feldman column they changed their policy about who could write "as told to" projects. After the Penn State coverage, the entire company seemed to understand that sexual abuse was part of the story about sports. My story did that to them.

Lipsyte: The takeaway from my exit interview with the editorial board I had wowed 18 months earlier was this: "Why should we pay you all this money when we get criticism for free?" They went for a partial answer. They made the ombudsman a "public editor" -which The New York Times had called its ombudsman, including my role model, Margaret Sullivan- but neutered it into a part-time job for someone working in the field. It was silly. And then they cancelled the job altogether. Not that they ever paid attention to often valid criticism. They were above criticism. To be fair, the Times was always resistant to the idea of a watchdog - it took a terrible scandal to get one. ESPN needs a watchdog now more than ever as the pressure from its financial partners - the sports leagues - only increases.

\section{Authors: From your standpoint, what are ESPN's main challenges in the current media environment?}

McBride: The intersection between politics and sports is getting more crowded and there is a lot of nuance to that conversation. They will continue to struggle with that, not only because their policies are lacking but also because it's a messy area. Just about 
every single media company is struggling with social media and how their employees are represented on social media.

Brady: They do a lot of really good work. It is not all great journalism, but not everything that is The Washington Post every day is great journalism, either. I do think they deserve credit for pushing as far as they do into journalism when they don't necessarily have to and it creates more trouble to them than not doing it. I think they suffer from a kind of institutional desire not to be transparent. I don't think they explain their decisions very well; they don't have particularly deep relationships with their consumers. I think they have a little bit of a challenge there in terms of better engaging with its audience. They are not used to being with the public. They are used to telling them what is going on but keeping the respectful distance.

Lipsyte: There's been an attempt to say they're losing customers because of their liberal bent, which is silly. They are losing customers for very practical financial reasons. And I think they're going to have to find a way to stem that. At the moment all they can think about is cutting staff and salaries. But I also wouldn't blame ESPN too quickly. They're a good bunch of people, actually. They really are in thrall to Disney shareholders. That's fine for Disney, because I'm not sure a blockbuster movie has to have journalistic integrity. But ESPN wants to have some journalistic integrity and that's hard when everything is about the bottom line. 